\title{
Lithospermum sylvestre (Boraginaceae): A new species from the Baviaanskloof, Eastern Cape, South Africa
}

\begin{tabular}{|c|c|}
\hline \multicolumn{2}{|c|}{$\begin{array}{l}\text { Authors: } \\
\text { James I. Cohen }{ }^{1} \text { (D) } \\
\text { John C. Manning } \\
\text { Doug Euston-Brown }{ }^{4} \text { (D) }\end{array}$} \\
\hline \multicolumn{2}{|c|}{$\begin{array}{l}\text { Affiliations: } \\
{ }^{1} \text { Applied Biology Program, } \\
\text { Kettering University, Flint, } \\
\text { United States }\end{array}$} \\
\hline \multicolumn{2}{|c|}{$\begin{array}{l}{ }^{2} \text { Compton Herbarium, } \\
\text { South African National } \\
\text { Biodiversity Institute, } \\
\text { Cape Town, South Africa }\end{array}$} \\
\hline \multicolumn{2}{|c|}{$\begin{array}{l}{ }^{3} \text { School of Life Sciences, } \\
\text { University of KwaZulu-Natal, } \\
\text { Durban, South Africa }\end{array}$} \\
\hline \multicolumn{2}{|c|}{$\begin{array}{l}{ }^{4} \text { Private, Scarborough, } \\
\text { South Africa }\end{array}$} \\
\hline \multicolumn{2}{|c|}{$\begin{array}{l}\text { Corresponding author: } \\
\text { John Manning, } \\
\text { j.manning@sanbi.org.za }\end{array}$} \\
\hline \multicolumn{2}{|c|}{$\begin{array}{l}\text { Dates: } \\
\text { Received: } 03 \text { Oct. } 2018 \\
\text { Accepted: } 29 \text { Jan. } 2019 \\
\text { Published: } 25 \text { June } 2019\end{array}$} \\
\hline \multicolumn{2}{|c|}{$\begin{array}{l}\text { How to cite this article: } \\
\text { Cohen, J.I., Manning, J.C. \& } \\
\text { Euston-Brown, D., 2019, } \\
\text { 'Lithospermum sylvestre } \\
\text { (Boraginaceae): A new } \\
\text { species from the } \\
\text { Baviaanskloof, Eastern Cape, } \\
\text { South Africa', Bothalia 49(1), } \\
\text { a2411. https://doi.org/ } \\
\text { 10.4102/abc.v49i1.2411 }\end{array}$} \\
\hline \multicolumn{2}{|c|}{$\begin{array}{l}\text { Copyright: } \\
\text { (C) 2019. The Authors } \\
\text { Licensee: AOSIS. This } \\
\text { is licensed under the } \\
\text { Creative Commons } \\
\text { Attribution License. }\end{array}$} \\
\hline \multicolumn{2}{|l|}{ Read online: } \\
\hline 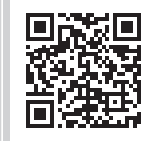 & $\begin{array}{l}\text { Scan this QR } \\
\text { code with your } \\
\text { smart phone or } \\
\text { mobile device } \\
\text { to read online. }\end{array}$ \\
\hline
\end{tabular}

Background: Recent field work in the Baviaanskloof, Eastern Cape, resulted in several collections of an unknown species of Lithospermum (Boraginaceae), a genus that is taxonomically relatively poorly understood in southern Africa.

Objectives: To describe the Baviaanskloof collections and characterise them against currently known species of Lithospermum.

Method: Relevant literature was surveyed and herbarium and fresh material was examined.

Results: Recent collections of Lithospermum from the Baviaanskloof Mountains in Eastern Cape represent an undescribed species.

Conclusion: Lithospermum sylvestre J.Cohen \& J.C.Manning is a new species recognised by its well-branched stems with adpressed-scabrid pubescence, and relatively long-tubed flowers with long styles that are \pm as long as the corolla tube and only shortly included within it.

Keywords: Boraginaceae; Lithospermum sylvestre; new species; South Africa; taxonomy.

\section{Introduction}

Lithospermum L. (Boraginaceae) is a genus of \pm 70 species of perennial (rarely annual) herbs or subshrubs widely distributed across both hemispheres, mainly in temperate latitudes, and it is particularly diverse in Mexico and the USA (Cohen 2018; Johnston 1952, 1954; Verdcourt 1991). The species exhibit moderate floral diversity, with white, yellow, orange or green corollas varying in shape from tubular to funnel-shaped or salver-form and ranging in size from $1 \mathrm{~mm}$ to over $60 \mathrm{~mm}$ in length. The anthers and stigmas are frequently included, but are exserted in several species, and the style is gynobasic. The smooth, shining nutlets are diagnostic for the genus. Their superficial resemblance with little stones is reflected in the generic name Lithospermum (stone seed) and the common name marbleseed.

Although the genus has been the subject of several recent phylogenetic (Cohen 2011; Weigend et al. 2009) and taxonomic studies (Cohen 2018; Weigend et al., 2010), these have focused on the New World taxa, representing the geographic region of greatest diversity of Lithospermum species. The African species, in contrast, have not been critically or comprehensively studied. Recent regional treatments exist for the Flora of Tropical East Africa (Martins 1990) and Flora Zambesiaca (Verdcourt 1991), although these differ in their circumscription (e.g. corolla colour) of the widespread African species L. afromontanum Weim., which is broadly distributed through the temperate grasslands of tropical and subtropical sub-Saharan Africa.

Lithospermum is taxonomically very imperfectly understood in southern Africa. Wright (1904), in his account of the genus for the Flora Capensis, recognised nine species, but this number was reduced to five by Johnston (1952) in his revision of the entire genus, with L. affine DC. and L. hirsutum E.Mey ex DC. treated as synonyms of L. scabrum Thunb. Most recently, the updated Checklist of South African Plants (Germishuizen \& Meyer 2003) once again listed eight species of Lithospermum, based largely on an unpublished thesis by Retief (2003), with one species, L. flexuosum Lehm., considered to be inadequately known.

Most of the recognised southern African species are characterised by stems with a pubescence of patent or spreading hairs, and relatively small flowers with corolla tubes less than $6 \mathrm{~mm}$ in length and styles \pm one-third the length of the corolla tube (Johnston 1952, 1954; Martins 1990; Verdcourt 1991). Several recent collections of Lithospermum from the Baviaanskloof Mountains in 
Eastern Cape, South Africa, however, are distinctive in their well-branched stems, with adpressed-scabrid pubescence and relatively longer tubed flowers with long styles. Comparison of these collections with the available literature and herbarium material leads us to conclude that these specimens represent an unknown species that we describe here as L. sylvestre in allusion to its characteristic habitat.

\section{Materials and methods}

Specimens or digital images of all relevant types as well as all herbarium material from BOL, NBG, PRE and SAM (acronyms after Thiers 2015) were examined as the primary collections of species from southern Africa. Specimens are cited following the Quarter Degree Reference System (Leistner \& Morris 1976).

\section{Taxonomy}

Lithospermum sylvestre J.Cohen \& J.C.Manning, sp. nov. Type: South Africa, Eastern Cape, Willowmore (3323): Baviaanskloof, entrance to Uitspan Kloof (-DA), $850 \mathrm{~m}$, 24 December 2017, D. Euston-Brown 5322 (NBG, holo.).

Bushy, perennial herb, 100-300 (-400) mm tall, stems erect or suberect, rod-like, $1.5-4.0 \mathrm{~mm}$ diameter, strigose, wellbranched with rather weak branches. Leaves cauline, sessile, spreading or weakly deflexed, blades elliptic to lanceolate, $(12-) 40-100(-120) \mathrm{mm} \times(2-) 6-10(-20) \mathrm{mm}$, obtuse to subacute, base attenuate, margins entire, planar, abaxially and adaxially thinly strigose, midrib raised adaxially and more densely strigose, hairs not bulbous-based, hair base surrounded by cystoliths, eucamptodromous. Inflorescence a terminal scorpioid cyme, sometimes with additional axillary monochasial cymes, elongating to $200 \mathrm{~mm}$ long in fruit; bracts spreading or weakly deflexed, sessile, lanceolate to linear lanceolate, $8-20(-35) \mathrm{mm} \times 2-10 \mathrm{~mm}$, subacute, base cuneate, margins entire, planar, abaxially and adaxially stigose, hyphodromous; pedicels $\pm 2 \mathrm{~mm}$ long. Flowers homostylous, chasmogamous. Sepals linear, subequal or slightly unequal, $2.5-3.0 \mathrm{~mm} \times 0.5 \mathrm{~mm}$ in flower, accrescent to $6-8 \mathrm{~mm} \times 0.8 \mathrm{~mm}$ in fruit and then spreading, acute, abaxially hispid, more densely so basally with longer hairs, adaxially strigillose. Corolla salver-shaped, pure white to creamy white, with pale greenish-yellow throat and tube, abaxially glabrous in basal half and puberulous in distal half, more densely so distally, tube $7-8 \mathrm{~mm} \times 2-3 \mathrm{~mm}$, adaxially sparsely pubescent at mouth and on base of lobes, lobes orbicular to elliptic, $3 \mathrm{~mm} \times 2-3 \mathrm{~mm}$, spreading, obtuse, gland-tipped hairs present within tube at stamen insertion and decurrent for $\pm 1.5 \mathrm{~mm}$ below filament insertion, faucal appendages present, partially obstructing throat, pouched, $\pm 1 \mathrm{~mm}$ diameter, hispidulous with mix of acute and scattered gland-tipped hairs, annulus a ring of 10 minute fleshy proturberances at base of tube. Stamens included, filaments subulate, $0.50-0.75 \mathrm{~mm}$ long, attached $6-7 \mathrm{~mm}$ above corolla base, anthers oblong, $1.50-1.75 \mathrm{~mm} \times 0.50 \mathrm{~mm}$; pollen ellipsoid to slightly ovoid, 9-13 $\mu \mathrm{m} \times 6-11 \mu \mathrm{m}$. Style filiform, 7-8 mm long, shortly included; stigmas terminal to sub-terminal, biparted. Nutlets erect, 3.0-3.5 mm $\times 2.0-2.5 \mathrm{~mm}$, obliquely ovoid, weakly keeled distally on outer face and shortly crested on inner face, apex acute, base truncate, smooth or irregularly pitted, glossy white to silvery grey, sometimes partially tan. Flowering time: October to February (Figures 1 and 2).

Distribution and habitat: Lithospermum sylvestre is evidently endemic to the western Baviaanskloof Mountains in Eastern Cape, South Africa, where it has been collected from a few sites on the southern side of the mountain range (Figure 3). The species is restricted to narrow gorges at $650 \mathrm{~m}$ to $850 \mathrm{~m}$ elevation as a component of the understory of the riparian forest. Plants are scattered in small, localised populations in rocky sandstone scree and talus, where they are subject to periodic disturbance when the rivers come down in spate. Associated species are typical forest and thicket elements of the region, including the trees Ficus sur Forssk. (Moraceae),

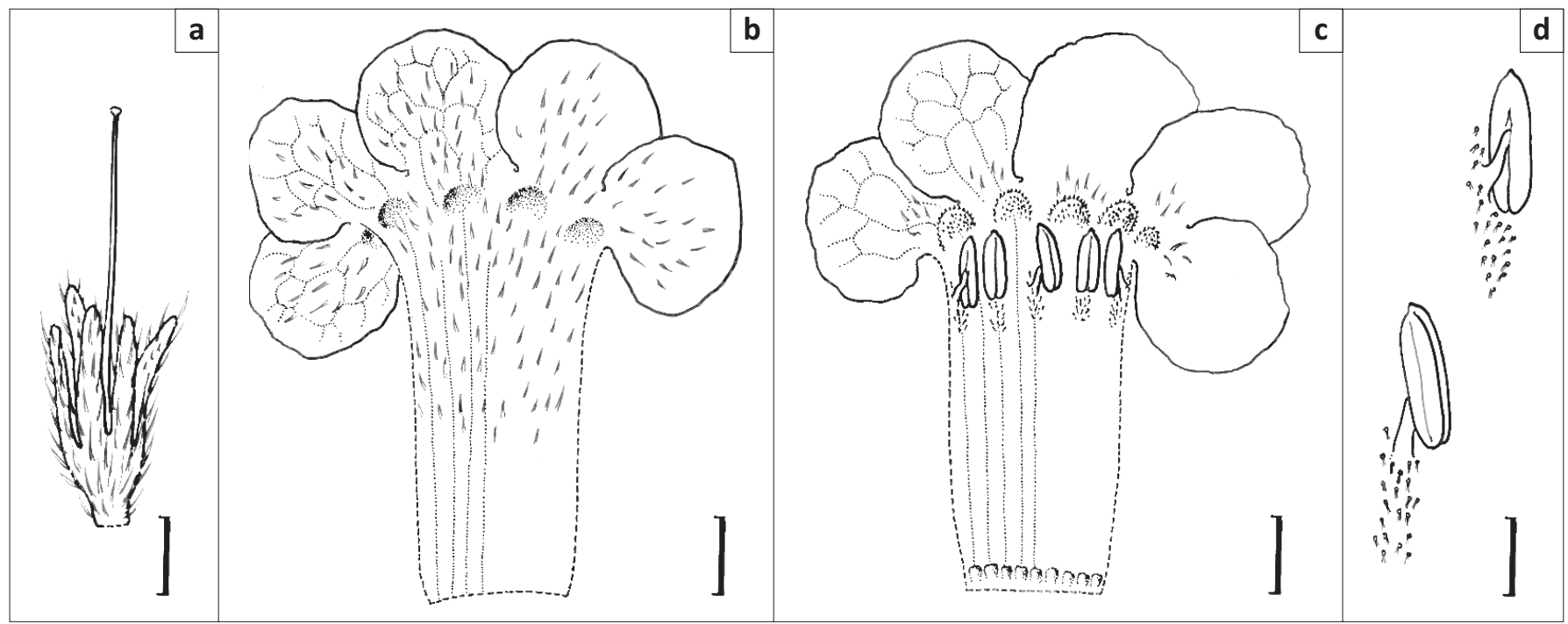

Source: Photo courtesy of John Manning

FIGURE 1: Floral details of Lithospermum sylvestre. (a) Calyx and style, (b) flattened corolla outer surface, (c) flattened corolla inner surface and (d) anthers showing distribution of gland-tipped hairs. Scale bar: (a)-(c) $2 \mathrm{~mm}$; (d) $1 \mathrm{~mm}$. 
Ilex mitis (L.) Radl. (Aquifoliaceae), Kiggelaria africana L. (Achariaceae) and Smelophyllum capense (Sond.) Radl. (Sapindaceae), and the shrubs Pelargonium zonale (L.) L'Hér. (Geraniaceae) and Plumbagoauriculata Lam.(Plumbaginaceae).

Diagnosis: Lithospermum sylvestre is distinguished from other South African species of the genus by its well-branched stems with adpressed-scabrid pubescence, relatively large, spreading leaves with plane blades mostly 40-100(-120) $\mathrm{mm}$ $\times 6-10(-20) \mathrm{mm}$, flowers with the corolla tube $\pm 1.5 \times$ longer than the calyx and glabrous below, with the style \pm as long as the corolla tube and only shortly included, and pollen that is ellipsoid to slightly ovoid and 9-13 $\mu \mathrm{m} \times 6-11 \mu \mathrm{m}$, the smallest of any known South African species. In its adpressed pubescence and spreading foliage leaves, it resembles the widespread L. afromontanum, but that species is characterised by acute to acuminate leaves with prominent veins beneath, and a corolla tube \pm as long as the calyx. Other superficially similar species such as L. affine, L. hirsutum and L. scabrum are immediately distinguished from L. sylvestre by the patent or spreading hairs on the stems, at least below (Wright 1904), whereas L. diversifolium DC. has smaller leaves with revolute margins (Wright 1904). The two remaining species recorded from southern Africa are very different: L. papillosum Thunb.
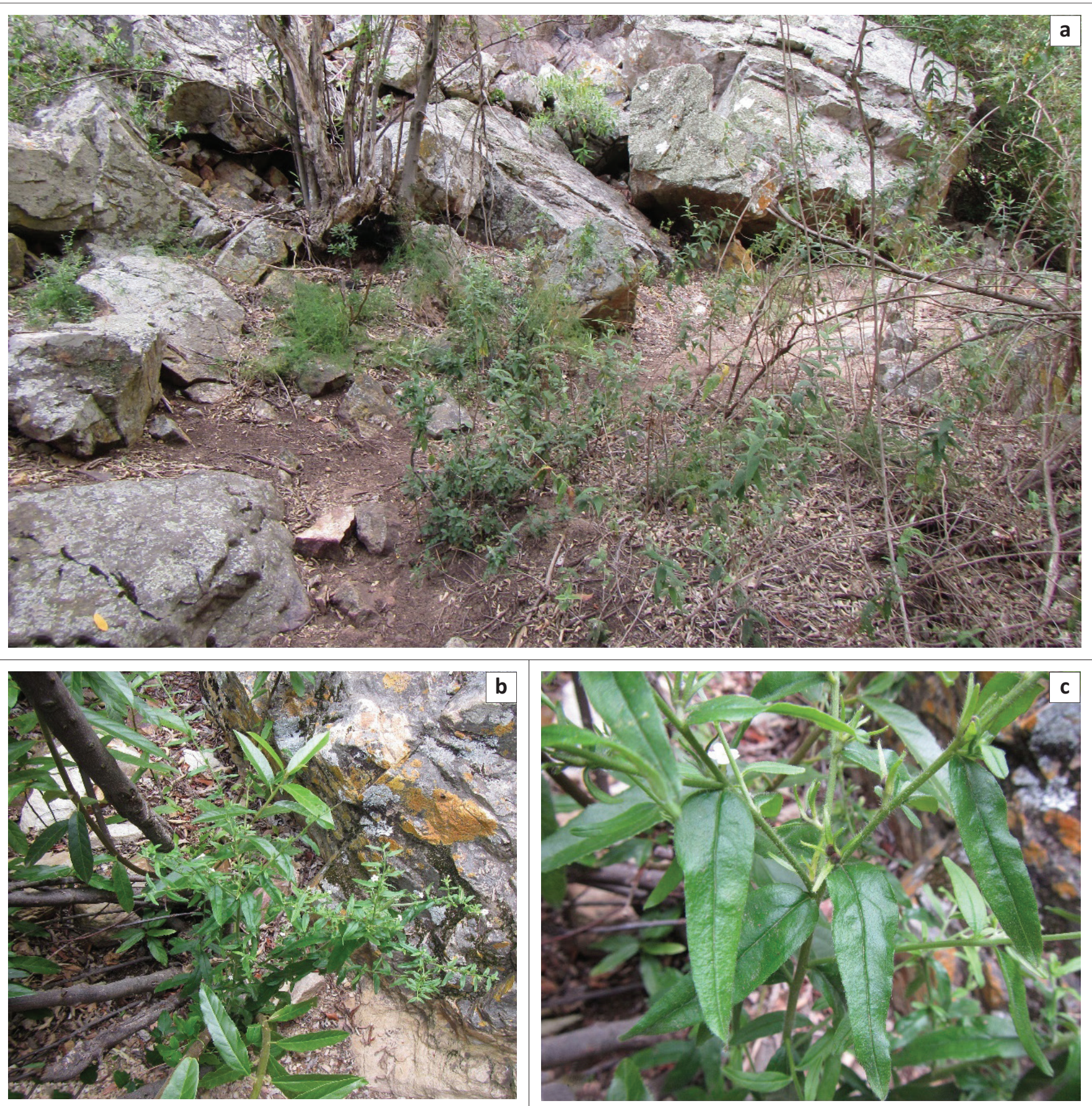

Source: Photo courtesy of Doug Euston-Brown

FIGURE 2: Lithospermum sylvestre. (a) habitat, (b) habit, (c) foliage, (d) flower side view, (e) flower front view and (f) nutlets. 

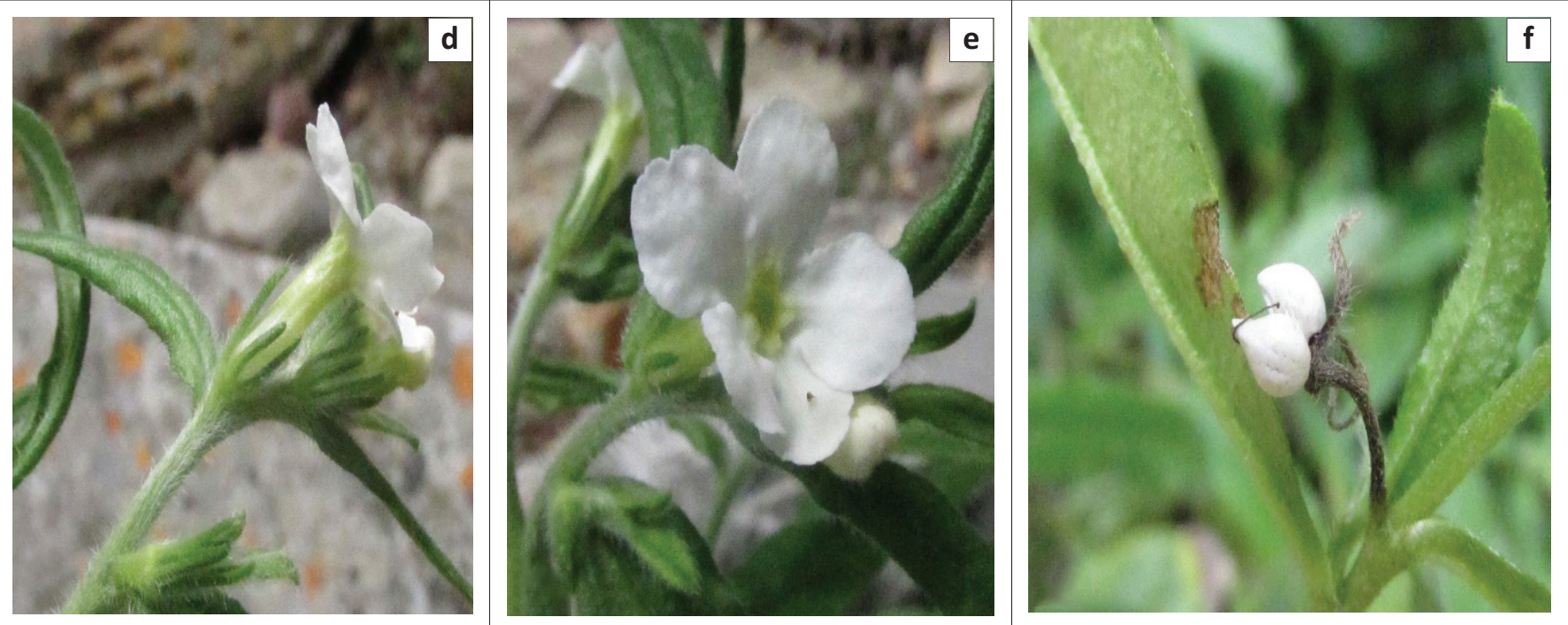

Source: Photo courtesy of Doug Euston-Brown

FIGURE 2 (Continues...): Lithospermum sylvestre. (a) habitat, (b) habit, (c) foliage, (d) flower side view, (e) flower front view and (f) nutlets.

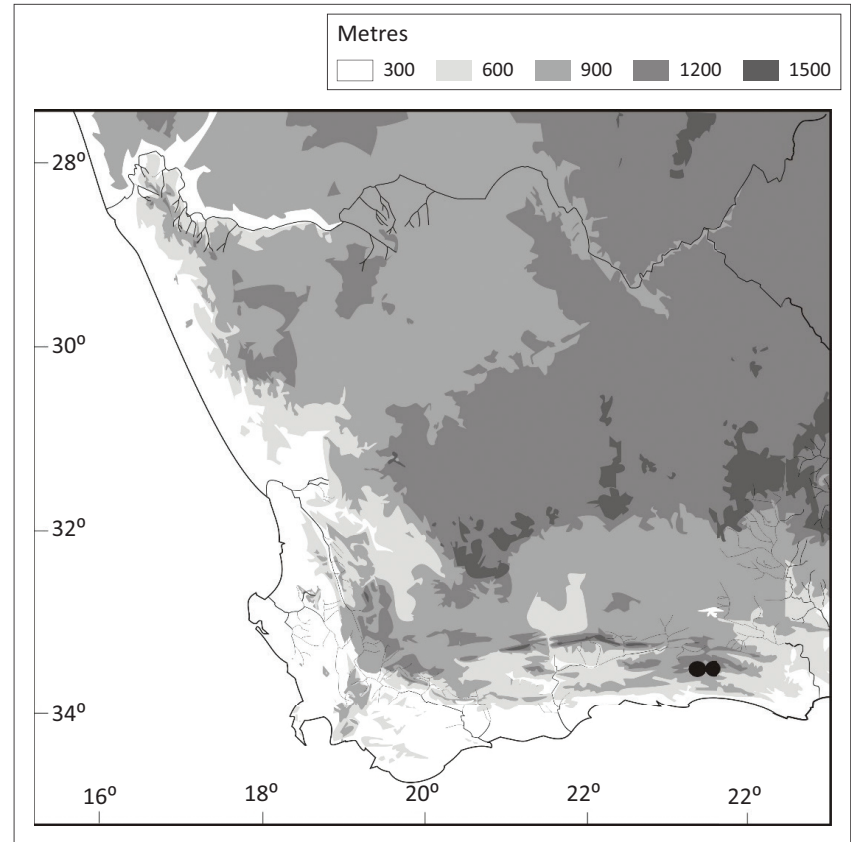

FIGURE 3: Distribution and habitat: Lithospermum sylvestre is evidently endemic to the western Baviaanskloof Mountains in Eastern Cape, South Africa, where it has been collected from a few sites on the southern side of the mountain range.

is a resprouting subshrub with mostly simple, erect stems with narrow, erect leaves with revolute margins; and L. cinereum DC. has small, narrowly oblong leaves up to $25 \mathrm{~mm}$ long densely covered with greyish pubescence.

Lithospermum sylvestre is most similar to L. afromontanum in gross morphology, but its pollen most closely resembles that of L. scabrum. This mix of character states is characteristic of species in Lithospermum (Cohen 2011, 2018).

Conservation notes: Lithospermum sylvestre is a local endemic known from four localities approximately $22 \mathrm{~km}$ distant from one another, with an area of occupancy less than $20 \mathrm{~km}^{2}$. Although only one of the localities falls within a formal conservation area, the others are located adjacent to protected catchment sites in relatively inaccessible places that are not currently under threat and that are unsuitable for agriculture or urbanisation.

\section{Additional specimens seen}

South Africa. EASTERN CAPE. 3323 (Willowmore): Baviaanskloof Mountains, Uitspan Kloof, near entrance to narrow kloof at Uitspan (-DA), 820 m, 19 February 2016, D. Euston-Brown 4608 (NBG); Baviaanskloof, Bo-Kloof, in dry streambed of Waterkloof (-DB), 839 m, 9 October 2016, D. Euston-Brown 5042 (NBG); Baviaanskloof, dry streambed of Kasey Kloof (-DB), 814 m, 26 December 2017, D. EustonBrown 5323 (NBG); Baviaanskloof, Dam se Kloof just before first chain ladder (-DB), 649 m, 27 April 2018, D. EustonBrown 5884 (NBG).

\section{Acknowledgements}

The authors would like to thank Michelle Smith for preparing the digital map and Luvo Magoswane for preparing the figures.

\section{Competing interests}

The authors declare that they have no financial or personal relationships that may have inappropriately influenced them in writing this article.

\section{Authors' contributions}

J.I.C. and J.C.M contributed taxonomic input; D.E.-B. collected the new species and provided ecological input.

\section{Ethical considerations}

This article followed all ethical standards for a research without direct contact with human or animal subjects. 


\section{Funding}

This research received no specific grant from any funding agency in the public, commercial, or not-for-profit sectors.

\section{Data availability statement}

Data sharing is not applicable to this article as no new data were created or analysed in this study.

\section{Disclaimer}

The views and opinions expressed in this article are those of the authors and do not necessarily reflect the official policy or position of any affiliated agency of the authors.

\section{References}

Cohen, J.I., 2011, 'A phylogenetic analysis of morphological and molecular characters of Lithospermum L. (Boraginaceae) and related taxa: Evolutionary relationships and character evolution', Cladistics 27, 559-580. https://doi.org/10.1111/j.10960031.2011.00352.x

Cohen, J.I., 2018, 'A revision of the Mexican species of Lithospermum (Boraginaceae)', Annals of the Missouri Botanical Garden 103, 200-257. https://doi.org/10.3417/ 2011067
Germishuizen, G. \& Meyer, N., 2003, Plants of southern Africa: An annotated checklist, National Botanical Institute, Pretoria.

Johnston, I.M., 1952, 'Studies in the Boraginaceae, XXIII. A survey of the genus Lithospermum', Journal of the Arnold Arboretum 33, 299-366.

Johnston, I.M., 1954, 'Studies in the Boraginaceae, XXVII. Some general observations concerning the Lithospermeae', Journal of the Arnold Arboretum 35, 158-166. https://doi.org/10.5962/bhl.part.8316

Leistner, O.A. \& Morris, J.W., 1976, 'Southern African place names', Annals of the Cape Provincial Museums 12. Grahamstown: Albany Museum.

Martins, E.S., 1990, 'Boraginaceae', in E. Launert \& G.V. Pope (eds.), Flora Zambesiaca $7(4)$, pp. 59-110, Flora Zambesiaca Managing Committee, Royal Botanic Gardens, Kew.

Retief, E., 2003, 'Boraginaceae', in G. Germishuizen \& N.L. Meyer (eds.), Plants of southern Africa: An annotated checklist, pp. 313-320, National Botanical Institute, Pretoria.

Thiers, B. 2015, Index Herbariorum: A global directory of public herbaria and associated staff, Botanical Garden's Virtual Herbarium, New York, viewed June 2017, from http://sweetgum.nybg.org/ih/.

Verdcourt, B., 1991, 'Boraginaceae', in R.M. Polhill (ed.), Flora of Tropical East Africa, p. 124, Royal Botanic Gardens, Kew.

Weigend, M., Gottschling, M., Hilger, H.H. \& Nürk, N.M., 2010, 'Five new species of Lithospermum L. (Boraginaceae tribe Lithospermeae) in Andean South America: Another radiation in the Amotape-Huancabamba zone', Taxon 59, 1161-1179. https://doi.org/10.1002/tax.594015

Weigend, M., Gottschling, M., Selvi, F. \& Hilger, H.H., 2009, 'Marbleseeds are gromwells - Systematics and evolution of Lithospermum and allies (Boraginaceae tribe Lithospermeae) based on molecular and morphological data', Molecula Phylogenetics and Evolution 52, 755-768. https://doi.org/10.1016/j.ympev. 2009.05.013

Wright, C.H., 1904, 'Boraginaceae', in W.T. Thiselton-Dyer (ed.), Flora capensis 4(2), pp. 2-45, Lovell Reeve, Kent. 